\title{
SPEECH THERAPY INTERVENTION WITH ARMENIAN-SPEAKING CHILDREN HAVING SOUNDS PRONUNCIATION DISORDERS
}

\author{
AUTHORS' DATA: \\ Geghecik Grigoryan, $\mathrm{PhD}$ in Education \\ Chair of Speech and Rehabilitative Therapy, Khachatur Abovyan Armenian State University \\ Lecturer \\ Head of Adaptation Unit in the Republican pedagogical-psychological center \\ Contacts: g.grigoryan77@mail.ru \\ Gohar Hovyan, $\mathrm{PhD}$ in Education, Associated professor \\ Chair of Speech and Rehabilitative Therapy, Khachatur Abovyan Armenian State University \\ Lecturer \\ Contacts: gohar.hovyan@ mail.ru
}

\section{ABSTRACT}

The purpose of this study is to present the peculiarities of speech therapy intervention with children with dyslalia and to analyze the specific patterns of Armenian speaking children sound pronunciation and speech perception, speech therapy conditions for overcoming speech problems, the relevance of teaching methods in the process of formation of pronunciation functions, which will contribute to the improvement of dyslalia under the application of appropriate methodic.

The methods of studying and analyzing the leading pedagogical experience of the teachers and speech therapists has been investigated within the frame of this research pedagogues and teachers, as well as the methods of psycho-pedagogical research: observation, conversation, inquiry were used. Different types of dyslalia, peculiarities of the speech therapy process, the rules of professional practice through the way of presentation and analysis of private cases, has been observed and analyzed, for exact determination of the direction and extent of speech therapy intervention in accordance with preventive interventions. 
Scientific justification of the appropriate methodological requirements, tools, and techniques used in the process of overcoming speech disorders of Armenian-speaking children is more effective if the speech therapy prevention techniques are used on early stages, as well as the methods of correcting dyslalia in accordance with the rules of Native language teaching enable effective speech therapy work in general education. This kind of systematic approach enables accounting the unique regularities of the Native language (in this case, the Armenian language); identify, evaluate, and coordinate sound pronancation disorders of mainstream school students; to implement the process of ontervention for overcoming speech problems of children with speech disorders.

Key words: dyslalia, speech therapy intervention, pedagogical-psychologiacl support, sound system, ways and methods of overcoming Armenian-speaking children speech disorders, prevention.

\section{INTRODUCTION}

The detection, study, diagnosis, prevention, and correction of speech disorders are the most important tasks of speech therapy that substantiate the specifics of the organization of speech therapy intervention for children with dyslalia based on the preventive intervention plan (Muñoz \& Córcoles, 2015). The timeliness of the chosen topic is conditioned by the timely demands of educational and social adjustment and is substantiated by the fact that the children with dyslalia require the choice of remedial methods, remedies, and options, according to the preventive intervention plan.

The speech therapist sets goals in the process of correcting dyslasia, with appropriate, specific methods, which are developed for the purpose of determining the small steps to achieve the long term goals (Acosta, 2012; Grigoryan, 2016; Grigoryan, 2018). First of all, the preventive intervention plan includes Specific, Measurable, Actionable, Realistic, Time constrained (SMART) goals. The goals set are summarized in the Achievements section, and the plan is drawn up for one semester (Acosta, 2012; Muñoz \& Córcoles, 2015). With regard to pedagogicalpsychological support services, the organization of educational-methodological, psychological, pedagogical, and speech therapy support is provided to the child, his or her parent, and teacher during the speech therapy intervention period. It is also important that the child's parents, friends, 
educators, and other professionals work together to provide support that will enhance child's selfesteem, activity, and participation in school, family life, and the society.

Thus, according to the order of the provision of pedagogical-psychological support services for the organization of education, the child assessment process is carried out in two phases, at the school and regional levels.

Observations conducted within the frame of current study allowed to evaluate the sequence of goals used in the organization of speech therapy intervention and speech correction of children with dyslalia, as well as the importance of tasks, and the effectiveness of the features of a preventive intervention plan (WHO ICF-CY, 2017; Gavrishov, 2016). It is also very important to state that in contrast with Individual Learnin Plan, the preventive intervention plan is made in shorter term. Speech therapy intervention with children with dyslalia according to the intervention plan enables speech therapist to set goals by phases.

Research conducted within the frame of this study has been organized in several interrelated phases, during which the actual theoretical materials were collected from Republican pedagogical-psychological support centre, secondary school № 145, inclusive school № 37 in Yerevan, and inclusive schol №1 in Gavar. The information related to children with dyslalia and the peculiarities of speech therapy intervention was collected (Gavrishov, 2016).

Apropos speech therapy intervention, which has long been focused on addressing speech problems, has become more effective and applicable. It allows the specialist to properly organize the process of speech therapy intervention (Grigoryan, 2017).

\section{LITERATURE REVIEW}

The speech development of children is highly significant. It is an important indicator of the development of children's cognitive abilities which is very important for later school achievements. Vardanyan, Hovyan, Amirbekyan and Grigoryan (2008) reflect to the practical tasks used in speech-language practice of speech disorders and to the writing skills of schoolaged children. Different types of dyslalia presented with different speech disorders, starting from acoustic-phonetic, pronunciation-phonetic, and finishing with disturbances in the formation of the phonetic side of speech due to the sensory link of the speech perception mechanism. In addition, the children with such a problem cannot distinguish this or that acoustic feature of a complex sound that usually makes it possible to contrast the sounds (Vardanyan, Amirbekyan, 
Hovyan \& Zohrabyan, 2007). As a result, the child perceives one sound instead of another, due to some commonalities. The substitution of one sound for another is taking place. Failure to recognize one or more of these attributes may misinterpret the sound, therefore also the word composed with that sound. This disadvantage interferes with understanding one's own words as well as those of others (Sukiasyan, 1999; Grigoryan, 2013).

In the process of literature review, the most important factor that has been taken into account was that the plan of preventive intervention was incorporating with the SMART goals which should in that particular case be drawn up taking into account the various forms of distal expression, including acoustic-phonetic, extracorporeal-phonetic-phonetic features (Vardanyan, Hovyan, Amirbekyan, Grigoryan, 2007). The suggested materials in Speech therapy in practice manual can also be helpful for parents (Speech Therapy in practice, 2017).

Grigoryan and Hovyan (2016) investigated the leading pedagogical experiences of teachers and analyzed the significance of the correlation between the central nervous system and verbal activity. The sounds of the language, as the only only characteristic of human beings, are developed within a child during several years from birth. This process includes the brain and speech apparatus. They are controlled by the central nervous system. Therefore, injuries to this system also have a negative impact on the formation of sound and pronunciation. The process of the sound pronunciation can be caused by deviations, temporal disturbances, mismatches, etc (Grigoryan \& Ovyan, 2016; WHO ICF-CY, 2017). Within the current study the peculiarities of the speech therapeutic intervention with Armenian-speaking children having dyslalia have also been touched upon.

Grigoryan (2013) in her article "Peculiarities of Speech Therapy in Correction of Speech Disorders" highlights the importance and the application of the preventive intervention plan, which incorporates the SMART goals of speech therapy intervention and the correction of dyslalia and other speech disorders. According to Jahukyan (2003) the phonetic diversity of minimum material units of language and the duration of the child's mastery of the phonological system is directly connected with the complexity of language sounds. The child should learn to perceive and reproduce the sounds. At the same time, it is necessary to recognize the sound with its distinctive features in which one sound contrasts with another. If a child does not learn to do this task, he will not be able to distinguish one word from another and recognize it as an identical in different word segments (Jahukyan, 2000). During the development of speech, a child's 
phonetic hearing is formed. This enables the recognition of sounds (speech phonetic casing). Phonetic hearing is primarily formed during the development of speech. It also develops audible listening, which is used to keep track of sounds in a continuous stream of syllables. Since the sounds are voiced by the pronunciation, it is important that these sounds be delivered in a regulated manner, that is, the standards adopted for the particular language system. Otherwise, they will be hard to to be perceived by the listener (Sukiasyan, 1999; Jahukyan, 2000).

A comparative analysis of the prevalence and communication peculiarities of speech disorders in Armenian-speaking, Russian-speaking and English-speaking children was made in the literature review process and it was confirmed that existing research has so far been carried out only in a limited number of separate studies and by very few authors [Jahukyan, 2000; Acosta, 2012; Grigoryan \& Ovyan, 2016).

Munoz and Corcoles (2015) have analyzed some of the speech disorders of children with dyslalia and the problems presented in children with speech disorders that are directly related to the organs involved in breathing and sound formation. While Acosta (2012) reflects on speech therapy features of practically often allied sound disorders, which mainly presents not only the complicated process of forming the phonetic side of speech, but also the child's communicative abilities, speech perception, and reproduction of the voice-controlled process.

According to many authors, the development of phonics should be seen not only as an important factor in beautiful communication, but also as an important issue in the teaching of the mother tongue, as insufficient development of the phonetic system, problems with sound perception substantially complicate students' learning and, at times, literacy.

As much as the recent decades of research in Armenian speech therapy has addressed the issues of the organization of speech therapy intervention for different speech disorders, it should be emphasized that the problems of overcoming speech disorders in Armenian-speaking children are, however, not fully theoretically and practically covered. It is no coincidence that even the majority of the urban population have no idea of the speech therapy service and, moreover, of the professional approaches and methods provided and demonstrated in speech disorders (Grigoryan \& Ovyan, 2016; Grigoryan, 2017). 


\section{METHODOLOGY}

\section{Participants and data collection}

More detailed research of the speech therapy intervention with children with dyslalia in accordance with the Preventive Intervention Plan Research was conducted within the frame of this study which has been organized in several interrelated phasesin the following placements: the Republican pedagogical-psychological support centre, secondary school № 145, inclusive school № 37 in Yerevan, and inclusive schol №1 in Gavar. The information related to children with dyslalia and the peculiarities of speech therapy intervention was collected (Gavrishov, 2016).

The following research method were used while data collection and data nalyzes:

- Study and analysis of professional literature;

- Study and analysis of the leading pedagogical experience of teachers;

- Study and analysis of medical and pedagogical documents of students with speech disorders;

- Observation, conversation, inquiry, examination, testing with speech cards;

- Pedagogical experience: confirming, and teaching,

- Using mathematical methods to generalize qualitative and statistical results.

The research materials were used to correct school-level disorders with a primary school assessment tool, which resulted in children with speech-language disorders. The speech therapy intervention on the problem-solving regarding speech-language-impaired children in different educational institutions was carried out with the help of theoretical and experimental methods.

Our research is completely presented in several interrelated phases. The results of the expert research phase were the basis for organizing and conducting a two-year teaching pedagogical experiment (2016-2018). In total, 172 children with speech disorders participated in the whole study, of which 86 (from first to fourth grade) participated in the expert survey (20162018). Of the tested learners, 56 are boys (65\%) and the rest are 30 girls (35\%). This phase of the study was conducted with social speechwriters and teachers (120), parents (110), students (74) on social awareness of speech impairment corrective learners. It was carried out through using developed questionnaires.

A preventive intervention plan has been developed for first to fourth graders in the field of speech therapy. The first page of the plan outlines the areas for special education needs and the 
problem of speech, that is, what to work on. Appropriate specialist (speech therapist, special educator, psychologist, occupational therapist) has worked in each relevant field.

As the insufficient development of the phonetic system, problems with sound perception substantially complicate students' learning and, in particular, literacy, the issues of spelling and orthography in the preventive intervention plan, as they are targeted at correcting speech disorders were also addressed.

Within the frame of research, methodological assignments were suggested: study of ontogenesis of speech development of Armenian speaking children with speech disorders, determination of the degree of speech disorder, elucidation of the causes of speech disorders, development of methods for assessment of speech disorders, and intervention methods (Vardanyan, Hovyan, Amirbekyan, Grigoryan, 2007).

\section{Data analyses}

Through analyzing the results of the survey by age of the children, it becomes obvious that accurate and complete sound pronunciation rates are increasing from grade to grade. Thus, if in the first grade $23.6 \%$ of respondents had positive indicators of speech disorder correction, in fourth grade the number increase till $46.5 \%$. In experimental group, after speech therapy intervention good and satisfactory results were distributed as follows (Table 1.)

Table 1. Positive indicators of speech therapy intervention according to grades.

\begin{tabular}{|c|c|c|}
\hline Grade & Good & Satisfactory \\
\hline First grade & $51.6 \%$ & $48.4 \%$ \\
\hline Second grade & $58.3 \%$ & $41.7 \%$ \\
\hline Third grade & $53.3 \%$ & $46.7 \%$ \\
\hline Fourth grade & $50 \%$ & $50 \%$ \\
\hline
\end{tabular}

It is obvious that the positive results in overcoming the problems of sound pronunciation in the experimental group are more noticeable. But, still despite the fact that positive results are quite obvious, the indicators studied in the control group in the fourth grade still remain low and the impairment of sound pronunciation is not overcome. Whereas, the problems of the experimental group's students in the fourth grade are almost solved. 
In this regard, the special attention should be paid to the need for the use of appropriate methods of preventing and correcting dyslalia and to continuing cooperation and training with native language teachers in elementary classes.

\section{The rationale of the study}

The rationale and reliability of the research results are ensured by a sufficient number of participants, the amount of work carried out, the use of modern and relevant research methods, and the thorough statistical processing of the actual experimental material.

\section{RESULTS}

The reliability and validity of the research results have been emphasized by a methodological approach based on scientific achievements in different fields, realization of systematic methods appropriate to the research objectives and the nature of the research findings, application of modern statistical methods, and detailed introduction of qualitative and quantitative results.

The development of unique means, methodological approaches and their implementation in the teaching of Armenian-speaking children with speech disorders have been implemented in accordance with the preventive intervention plan. Experiential special assignments, exercises and games for correction and rapid development of speech abilities were offered for overcoming phonetic disorders, phonetical perception skills.

The results of the research also indicated the existence of a number of issues not addressed within the frame of this, both theoretically and practically.

An overview of the experience of mainstream and inclusive schools as well as investigation of the intervention conducted by the speech therapists' working in the Republican Pedagogicalpsychological support center have shown that scientific studies aimed at correcting phonetic disorders do not fully satisfy the process of correcting speech disorders of children with dyslalia. As a rule, they are not applied in the practice and require multilevel and extensive studies.

Consequently, there is a need for development new methodological system for correction of speech disorders, as well as new programs, materials, methodological approaches and techniques for both specialists working in the field and parents. 
This speech disorder, which is more common in elementary school, impedes the realization of the learning process as it is characterized by persistent and repetitive phonetic errors, and forms a basis for both phonetic and pronocation functions.

In this regard, the development of a preventive intervention plan should pay particular attention to the need to apply appropriate methods of preventing and correcting dyslalia and to cooperating and continuing training with native language teachers in elementary school. For the solution of the existing problem, we consider the introduction and application of methods of correction of dyslasia which, in accordance with the regularities of teaching the mother tongue, will enable to carry out effective speech therapy intervention in general education.

We consider very important to emphasize the fact that in the case of speech therapy intervention, the peculiarities of the native language, and in this case, of the Armenian language, are not taken into account. This justifies the need to develop a plan we have chosen to substantiate the relevant methodological requirements, tools, and techniques used in the process of correcting speech disorders in Armenian-speaking children. In this case, using a preventive intervention plan can more effectively help students with speech disorders if:

- the prevention of dyslalia of Armenian-speaking children, assessment of verbal need, correction, organization of consulting activities, practical methods and means are clarified;

- methods of correction of dyslalia in the speech therapy intervention process, which, in accordance with the regularities of the teaching mother tongue are used in order to enable effective speech therapy intervention in general education.

Thus, the methodological analysis of the speech therapy intervention and the correction of the speech disorders, as well as the results of the research allows to prove that the complex methods of correcting the pronunciation of the Armenian consonants used in the elementary school are mainly aimed at the learners unmistakable phonetic formation as much as it is possible. However, in this work there are almost no approaches to speech therapy intervention that are appropriate to the native language practice of students with speech disorders in the grades 1-4.

It is interesting to note that the speech therapists did not attach importance to the use of systematic methods in correcting speech disorders and did not conform to the practice of teaching their native language. Despite this circumstance, however, the testers have positive indicators of overcoming the problems of sound pronunciation. Under these conditions, only 34 of the 86 participants in control group (29.4\%) had the correct sound pronunciation (Table 2). Through 
analyzing the results of the survey by age, it is not difficult to notice that accurate and consistent sound prononcation rates are increasing from grade to grade. Thus, while $23.6 \%$ of the participants had positive indicators of correction of speech disorder, in the fourth grade the number increses till $46.5 \%$ (Table 2).

Table 2. Positive indicators of dyslalia correction.

\begin{tabular}{|c|c|c|c|c|c|c|c|c|c|}
\hline \multirow[t]{4}{*}{ Grade } & \multirow{4}{*}{$\begin{array}{c}\text { Photics } \\
\text { level }\end{array}$} & \multicolumn{8}{|c|}{ Experimental groups } \\
\hline & & \multicolumn{4}{|c|}{$\begin{array}{l}\text { Experimental goup } n=86 \\
\text { I grade } n=31 \\
\text { II grade } n=24 \\
\text { III grade } n=15 \\
\text { IV grade } n=16\end{array}$} & \multicolumn{4}{|c|}{$\begin{array}{l}\text { Control group } n=86 \\
\text { I grade } n=31 \\
\text { II grade } n=24 \\
\text { III grade } n=15 \\
\text { IV grade } n=16\end{array}$} \\
\hline & & \multicolumn{2}{|c|}{$\begin{array}{c}\text { Before } \\
\text { experiment }\end{array}$} & \multicolumn{2}{|c|}{$\begin{array}{c}\text { After } \\
\text { experiment }\end{array}$} & \multicolumn{2}{|c|}{$\begin{array}{c}\text { Before } \\
\text { experiment }\end{array}$} & \multicolumn{2}{|c|}{$\begin{array}{c}\text { After } \\
\text { experiment }\end{array}$} \\
\hline & & $\mathbf{N}$ & $\%$ & $\mathbf{N}$ & $\%$ & $\mathbf{N}$ & $\%$ & $\mathbf{N}$ & $\%$ \\
\hline \multirow[t]{3}{*}{ I } & Good & - & - & 16 & 51.6 & - & - & 10 & 33 \\
\hline & Satisfactory & 17 & 54.8 & 15 & 48.4 & 16 & 51.6 & 15 & 48 \\
\hline & Insufficient & 14 & 45.2 & - & - & 15 & 48.4 & 6 & 19 \\
\hline \multirow[t]{3}{*}{ II } & Good & - & - & 14 & 58.3 & - & - & 9 & 37.5 \\
\hline & Satisfactory & 14 & 58.3 & 10 & 41.7 & 12 & 50 & 10 & 41.8 \\
\hline & Insufficient & 10 & 41.7 & - & - & 12 & 50 & 5 & 20.7 \\
\hline \multirow[t]{3}{*}{ III } & Good & - & - & 8 & 53.3 & - & - & 5 & 33.3 \\
\hline & Satisfactory & 10 & 66.6 & 7 & 46.7 & 10 & 66.6 & 7 & 46.7 \\
\hline & Insufficient & 5 & 33.4 & - & - & 5 & 33.4 & 3 & 20 \\
\hline \multirow[t]{3}{*}{ IV } & Good & - & - & 8 & 50 & - & - & 7 & 43.7 \\
\hline & Satisfactory & 8 & 50 & 8 & 50 & 8 & 50 & 7 & 43.7 \\
\hline & Insufficient & 8 & 50 & - & - & 8 & 50 & 2 & 12.6 \\
\hline \multirow[t]{3}{*}{ Total } & Good & - & - & 46 & 53.5 & - & - & 31 & 36 \\
\hline & Satisfactory & 49 & 56.9 & 40 & 46.5 & 46 & 53.4 & 39 & 45.4 \\
\hline & Insufficient & 37 & 43.1 & - & - & 40 & 46.6 & 16 & 18.6 \\
\hline
\end{tabular}


In the context of speech therapy intervention, the developed systematic approach will allow accounting the unique patterns of the mother tongue, in this case the Armenian language, to identify, evaluate and coordinate the phonetic disorders of secondary school students, to contribute the learning process of children with speech disorders, to form a basis for both sound and pronunciation transactions.

Based on the purpose of the study, the following objectives for speech therapy intervention were planned:

1. To study and evaluate the speaking abilities of Armenian-speaking children in the educational process and to select effective speech therapy methods for speech development.

2. To analyze the specific patterns of development of phonetic perception of children with speech disorders, the speech therapy intervention conditions, the relevance of teaching methods in the formulation of extracurricular functions that, in the application of appropriate methodology, will contribute to the improvement of dyslalia.

3. To define the speech therapy methods for overcoming the speech disorders of Armenianspeaking children in the Preventive Intervention Plan, and experimentally substantiate their effectiveness.

\section{DISCUSSION}

The main findings, conclusions, and results of the study will be discussed during the developing professional seminars, training and lectures, and at the same time may serve as a basis both for the introduction of new research and practical experience. Thus, studies on the correction of dyslalia in elementary school, which include the investigation of phonetic features of the Armenian language system and the speech-language skills of Armenian-speaking children, allow for the detection of dyslalia corrections. The use of theoretically and scientifically grounded methods and tools aimed at develop the characteristics of Armenian-speaking children makes the correction of dyslalia more effective and perfect based on the features of the mother tongue.

The timely organization of speech therapy intervention with students with speech disorders contributes both to the development of children's speech, as well as to the complete formulation and social adaptation of the written word process (Jahukyan, 2000; Grigoryan, 2013; Grigoryan \& Ovyan, 2017; Complite Speech Therapist reference, 2011). 
Pedagogical observations and assessments of the efficacy of speech therapists' intervention working with students with speech disorders enabled them to coordinate the needs of speech therapists and the needs of Armenian-speaking children with dyslalia, which are systematically tailored to the research objectives and the nature of the research findings.

The analysis of the experimental data allows to prove that the disorders of the students connected with phonetics in the elementary school are not completely overcomed, which proves that incompleteness of the speech work performed or the performance of the work which is incompatible with the native language.

Thus, multivariate analyzes of the causes of phonetics deficiencies allowed assessing learners' perception and hearing impairment, identifying problems that arise in the distinction of phonemes (phonemes and deaf consonants, syllables, and syllables), followed by difficult syllables. At the same time, the deficiencies of the phonemes, which are expressed by the substitution and confusion of the sounds in the words, have in turn made it difficult to develop the phonetic hearing and lead to disorders of writing and reading (Grigoryan, 2013; Grigoryan, 2016; Grigoryan \& Ovyan, 2016; Muñoz \& Córcoles, 2015).

Coordinating unique Armenian patterns in the process of correcting dyslalia allowed us to assess learners' coping abilities, realize the process of coping with Armenian-speaking children, and develop the ability of young students to develop sound perceptions. Such a systematic approach in the context of speech therapy intervention will allow to determine the efficiency of correcting dyslalia in accordance with the native language as a key indicator of the development of phonetic and articular functions (Ter-Grigoryan, 1980; Pokladova \& Razumova, 2005; Efimenkova, 2016; Grigoryan, 2017).

The research once again proves that in the process of correction of speech disorders while organizing speech therapy intervention, the development of methods of assessment, coordination, correction methods and measures, principles, improvement of preventive methods should be taken into account and emphasized (Efimenkova, 2016; Soshikova, 2018).

\section{CONCLUSION}

Thus, emphasizing the sequence of goals specified in the organization of speech therapy intervention and speech correction while working with children having dyslalia, the importance and effectiveness of tasks under the preventive intervention plan becomes very important. In the 
conducted research speech-specific features were specifically distinguished starting from the neutral condition to sound production (Jahukyan, 2003; Acosta, 2012).

Within the frame of this study, at the first stage, the traditional means of carrying out speech therapy intervention, provided information on the content of the training, the rules, the functions of each, and the actions, and developed the pronunciation skills that were considered necessary for sound were strongly emphasized (Ter-Grigoryan, 1980; Speech therapy in practice, 2017).

In the second phase of the pedagogical experiment, unlike traditional means of correcting speech problems, children with dyslalia, according to the developed methods and conditions performed certain tasks and exercises in the development of pronunciation abilities and skills before proceeding to the actual stage of sound production. Those tasks refer also to the development of hearing, the observation of sounds in a continuous stream of syllables. Since the sounds are voiced using the voice, it is important that these sounds are delivered in a regulated manner, that is, the standards adopted for the particular language system. Otherwise, they will be hard to hear and recognize. To this end, various exercises and tasks have been performed using a variety of pronunciation exercises and tasks, with consonant rules and a certain sequence.

The sequential performance of game exercises and tasks is aimed not only at developing perceptions of children with dyslalia, but also in the development and improvement of a large number of repetitive singular movements, in the development and improvement of phonetic functions and sound perception. With the above mentioned principles in mind, the process of overcoming the problems of the Armenian-speaking children and the development of the vocational perception of the young pupils was implemented.

Within the frame of speech therapy intervention, this kind of systematic approach has been enabled to determine the effectiveness of correcting dyslalia in accordance with native language norms as a key indicator of the development of phonetic and articular functions.

\section{REFERENCE LIST}

1. Acosta, R. (2012) Logopedic intervention in specific language disorders. Journal of Speech Therapy, Phonetics and Audiology, 32, 67-74.

2. Arokhjapahutyan hamashkharhayin kazmakerputyan, funkcionalutyan, hashmandamutyan ev aroghjutyan mijazgayin dasakargum. erekhaner ev eritasardner. (World Health Organization 
International Classification of Functionality, Disability and Health, Children and Youth) FMDEE, 2017, pashtonakan hayeren targmanutyun

3. Efimenkova, L. N. (2016) Organizacii I metodi korrekcionnoy raboti logopeda na shkolnom logopunkte (Organization and methods of correctional work of a speech therapist at a school speech center), L. N. Efimenkova, G.G. Misarenko - M.: Prosvesheniye, s.240.

4. Gavrishov, E. (2016) Quest-igrowaq forma kompleksnogo resheniya obrazovatelnikh zadach w korrektsionnoy gruppe; E. Gavrishova, O. Berezka, S. Zvyagintseva, V. Milemko, Doshkolnoe vospitanie (Quest - game form of a complex solution of educational problems in a correctional group) №5. - s. 79-84.

5. Grigoryan, G. F. (2017) Didakticheskie osnovi logopedii (Didactic basics of speech therapy), "Sovremennoe obrazovanie": Aktualniye voprosi, dostijeniya I innovacii: sbornik statey Xl mejdunarodnoy nauchno-prakticheskoy konferencii. Penza, s.157-160.

6. Grigoryan, G. F. (2013) Khosqayin khangarumneri shtkman gorcyntacum irakanacvogh logopedakan ashkhatanqi arandznahatkutyunnery (Peculiarities of Speech Therapy in Correcting Speech Disorders), "Kantegh" gitakan hodvacneri joghovacu N 2(55), Yerevan, Asoghik hratarakchutyun, ej 252-258

7. Grigoryan, G. F. (2016) Rol art-terapii pri vedenii korrekcionnikh rabot s detmi s rechevimi rasstrojstvami (Role of Art therapy while organizing intervention with children with speech disorders), "Nauchniy potencial” Nauchno-issledovatelskiy institute pedagogiki i psikhologii N 22(22), Cheboksari, s. 23-29.

8. Grigoryan, G. F., Ovyan, G. R. (2017) Aktualnost problem korrekcii zvukoproiznosheniya u detey s narusheniyami rechi (Relevance of the problem of correcting sound pronunciation in children with speech disorders). "Sovremennoe obrazovanie": Sbornik statey X mejdunarodnoy nauchno-prakticheskoy konferencii. Penza, s. 101-106.

9. Grigoryan, G. F., Ovyan, G. R. (2016) Hayakhos erekhaneri hnchartaberman khangarumneri shtkman arandznahatkutyunnery (Peculiarities of correcting speech disorders of Armenianspeaking children) "Kantegh" gitakan hodvacneri joghovacu N 4(69) Yerevan, Asoghik hratarakchutyun, ej 127-135

10. Jahukyan, G. B. (2003) Universal theory of language, Ann Azboz; p. 335.

11. Jahukyan, G. B. (2000) Hayoc lezvi tesutyan ev patmutyan himnaharcery, Yerevan - Beyrut, 406 ej 
12. Logopedian gortsnakanum (Speech therapy in practice) (2017), heghinakayin hratarakchutyun 76 ej, ej 4-7

13. Muñoz, P. R., Córcoles, S. C. (2015) Language disorders, Early indicators of language disorders, Language Intervention Center: 11, 57-61.

14. Pokladova, T. A., Razumova, Yu. R. (2015) K oprosu o korrekcii narusheniy zvukoproiznosheniy u detey s dislaliley (On the issue of correcting sound pronunciation disorders in children with dyslalia), Razumova Yu. R., Burova N. I., Teoriya i praktika obucheniya i vospitaniya detey s ogranichennimi vozmojnostyami zdorovya: sbornik nauchnikh statey po itogam nauchno-issledovatelskoy raboti prepodavateley I studentov fak. korrekc. pedagogiki ChGPU za 2014-2015 ucheb. god. - Chelyabinsk, s. 137-141.

15. Polniy spravochnik logopeda (Complete speech therapist reference) (2011), Avtor soatav. L. Smirnova, - Minsk: Kharvest, - 384 st., s. 247-253.

16. Soshnikova, N. G. (2018) Artikulyacionnaya gimnastika kak sredstvo korrekcii zvukoproiznosheniya u detey doshkolnogo vozrasta s dislaliey (Articulatory gymnastics as a means of correcting sound pronunciation in preschool children with dyslalia), Soshnikova N.G., Efanova E.V., Mir specialnoy pedagogiki i psikhologii: nauchno-prakticheskiy albom Moskva, s. 135-138.

17. Sukiasyan, A. M. (1999) Zhamanakakic hayoc lezu. Hnchyunabanutyun, baragitutyun, barakazmutyun (Modern Armenian language. phonetics, lexicology, vocabulary). 3-rd hratarakchutyun, Yerevan, ERH hrat., ej 157-250

18. Ter-Grigoryan, A. E. (1980) Hayoc lezvi dasavandma metodika; tarrakan dasaranner (Methodics of teaching Armenian language; elementary classes) Yerevan, 564 ej, ej 327-331

19. Vardanyan, A., Amirbekyan, G., Hovyan, G., Zohrabyan, Z. (2007) Gravor khosqi khangarumneri shtkman ughghvac varjutyunneri dzernark (Handbook of exercises to correct writing disorders), HH KGN KAI, Usumnametodakan dzernark, Asoghik gratun, Yerevan, 25 tp. mamul, ej 13-17

20. Vardanyan, A., Hovyan, G., Amirbekyan, G., Grigoryan, G. (2008) Yerekhaneri hnchartaberman terutyunneri shtkman ashkhatanqner (Correction of defects in children's sound performance) HH KGN KAI, Dzernark logopedneri hamar, ej 4-9, 13-19, 28-31 